\title{
Morphological Studies on the Relationship between Liver Damage and Steroidhormone Producing Organs
} Part I. Morphological Findings in Steroidhormone Producing Organs, especially the
Adrenal Cortex, in Human Liver Diseases

By

\section{Hiroyuki MURAKAMI}

2nd Division, Department of Internal Medicine, Medical Faculty, Kyoto University

(Director Prof. T. Miyake M.D.)

The morphology of steroidhormone producing organs, especially the adrenal cortex, was studied in 134 cases of human liver diseases, such as atrophy, cirrhosis and carcinoma of the liver.

1) In each case of acute hepatitis there were hypertrophy, necrosis and hemorrhage of the adrenocortical cells. The lipid granules in the adrenal cortex became much finer and less in content.

2) In cases of subacute or chronic hepatitis (liver atrophy), no marked histological changes were recognized in the adrenal cortex except for a diminution in number and irregular distribution of the lipid granules in the fasciculata.

3) In the fasciculata of the adrenal cortex in the cases of liver cirrhosis, especially of atrophic cirrhosis, morphological changes were not remarkable. The fasciculata did not undergo any significant changes except that the lipid granules became coarse, while the glomerulosa showed striking changes, such as becoming finer and a marked depletion or disappearance of the lipid granules. There were some deposits of brown pigment in the cytoplasm of the reticular cells.

4) Whenever there was much jaundice, there were marked necrotic or degenerative changes and a decrease of lipid droplets in the adrenal cortex.

5) Histological findings of the adrenal cortex in the cases of liver carcinoma were essentially the same as in cirrhosis of the liver. However, in the cases with advanced liver cancer and severe emaciation and jaundice, the lipids in the adrenal cortex were greatly diminished.

6) In the cases of liver disorders, there were generally atrophic changes in the testicles, such as decreased spermatogenesis, thickening of the basal membrane and proliferation of the connective tissue in the interstitium. On the other hand, Leydig's cells showed no atrophic changes, but in many cases there were a few deposits of brown pigment in the protoplasm.

7) The ovaries showed no specific pathological changes in any case of human liver disease. But a decrease in follicle formation and an enlargement of the lipid granules in the theca interna and lutein cells were sometimes seen.

8) The above observations suggest that abnormalities of steroidhormone metabolism in cases of chronic liver damage, especially cirrhosis, do not result from faulty hormone synthesis by the steroidhormone producing organs, but are probably caused by disturbances in the process of steroidhormone metabolism in the liver. The abnormalities in steroidhormone metabolism had continued over a long period and were followed by morphological changes in steroidhormone producing organs. 


\title{
肝蔵とステロイドホルモン産生蔵器との 関連に関する形態学的研究
}

\author{
第一編 肝疾患時にみられるステロイドホルモン産生臓器, \\ 殊に副腎皮質の形態学的所見について
}

京都大学医学部内科第 2 講座（指導 三宅篗教授）

医学士村上弘行

緒 言

各種肝疾患殊に肝硬変症に際して，種々の内分泌異常を件うことは古くより注目され，まずCorda (1925) Silverstrini (1726) 等が肝硬変に際して女性乳房・睪丸の萎縮の存在を指摘して，内分㦚失調によるものと 考えた200). 㗨にその後体毛分布の変化(Eppinger 1925, Jacob 1934)・性機能障害(Eppinger 1937, Bean 1945) 等の存在も認められ20)，また肝硬変症にしばしばみられるクモ状血管腫（Honot＆ Gilbert 1890）・手掌紅斑 (Chalmers 1899) もステロイドホルモン (SH) 代謝, 殊に過エストロゲン症ないしは Androgen-Estrogen 平衡の異常に由来するむのと考元られ $\left.{ }^{2}, 18,20,27\right)$ ，今日ではこのような内分泌異常所見が肝硬変症の診断の一 指標ともふなされている。

一方実験的研究においても，Zondeck (1933)・Silberstein (1934) 等が初仯て臟に Estrogen を不活性化

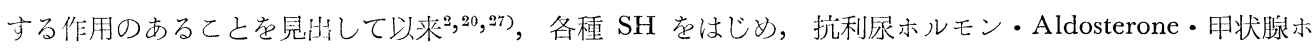
ルモン等も肝において不活性化されることが相次いで認められた ${ }^{18)}$. また最近 SH の代謝を論ずる埸合に

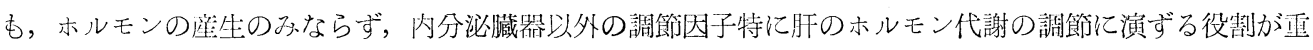
視されている”．そして肝障害時における SH 代謝の異常についての生化学的研究は, まさに枚挙のいとま あない程の多数にのばつているにも拘らず, $18,24,27,44$, 各種肝疾患に際してみられる内分泌臟器, $, 8,18,20,38,41)$ 就中副粲皮質 $1,6,18,20,23,39)$ につての形態学的研究は意外に少く, 殊に詳細な組織化学的方法を駆使しての 系統的研究は㱠んどるられない。

そこで私は肝臟とSH 産生藏器との関連について改めて形態学的に種々検討を行つているが，まず本編で

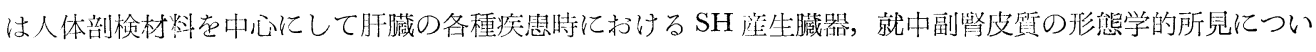
て，23の新しい知見をうるととができたのでその成績について報告する.

\section{研究材料並びに研究方法}

材料は京大病理学教室および大津赤十字病院において病理解剖を行つた各種肝疾㭧134例のSH産生臟器で あるが，その内訳は副腎134例・卵巣49例および窣丸85例で，第 1 表に総括してある.

これらの材湖はすべて中性ホルマリンで十分固定し水洗を行つてから，10〜20 没の涷絬切片を作成して， 表 2 のうな脂質に関する組織化学的検索を行つた。尚睪丸については，すべてゲラチン包埋を用いている.

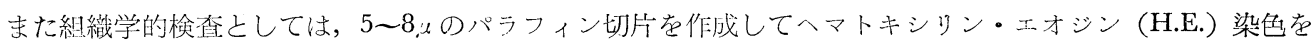
行つた，尚，刘照例としては父通事故による急死例並びにシアンカリ腿毒例で正常副腎と考元られるものを

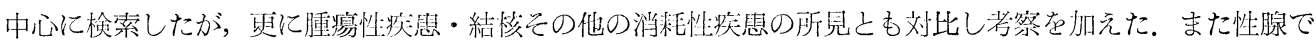

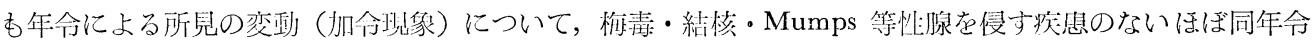
鱼を刘照として研究を進むた。

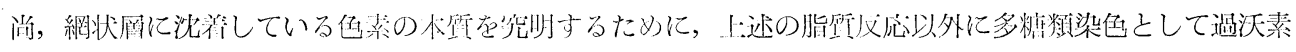


表 1

\begin{tabular}{|c|c|c|c|}
\hline & 男 & 支 & 計 \\
\hline $\begin{array}{l}\text { 急性黄色肝萎縮 } \\
\text { (急性 肝 炎) }\end{array}$ & 2 & 2 & 4 \\
\hline $\begin{array}{l}\text { 带急性黄色肝萎縮 } \\
\text { (亜急性乃至慢性肝炎) }\end{array}$ & 2 & 1 & 3 \\
\hline 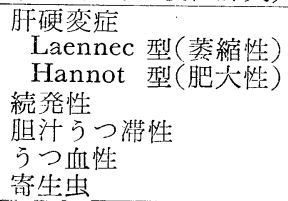 & $\begin{array}{r}17 \\
1 \\
12 \\
11 \\
1 \\
2\end{array}$ & $\begin{array}{l}4 \\
0 \\
7 \\
5 \\
1 \\
0\end{array}$ & $\begin{array}{r}21 \\
1 \\
19 \\
16 \\
2 \\
2\end{array}$ \\
\hline $\begin{array}{l}\text { 朋藏癌 } \\
\text { 原発烧 } \\
\text { 転移性(絸発性) }\end{array}$ & $\begin{array}{l}22 \\
15\end{array}$ & $\begin{array}{l}15 \\
14 \\
\end{array}$ & $\begin{array}{l}37 \\
29 \\
\end{array}$ \\
\hline 計 & 85 & 49 & 134 \\
\hline
\end{tabular}

表 2 私の用いた脂質打よびケトス テロイドの組織化学的方法

1) Sudan IV 染色

2) 重屈折性

3) 自働螢光性

4) Schultz 氏反応 ${ }^{32}$

5) Carbonyl 反応

Schiff 反応

Ashbel-Seligman 反応 $\left(\mathrm{A}-\mathrm{S}\right.$ 反応 $\left.{ }^{4.5}\right)$

6）アセトン浴解性

7) Smith-Dietrich反応 ${ }^{36)}(\mathrm{S}-\mathrm{D}$ 反応 $)$

酸一Schiff 反店 $(\text { PAS 反応 })^{22)}$ ，鉄反応として Perls ${ }^{28}$-Stieda ${ }^{37}$ 氏法を陚引た。

尚，文中に頻繁に現われる術語に対し，下記の略学を用いた。

ステロイドホルモンー SH

副腎皮澌ホルモン—CS

Ashbel-Seligman 反店-A-S 反応

Smith-Dietrich 反店-S-D店

ヘマトキシリン・エオジン染色—-H.E.染包

ケトフテロイド—-KS

結果

\section{I，副腎}

\section{（1）急性黄色肝萎縮}

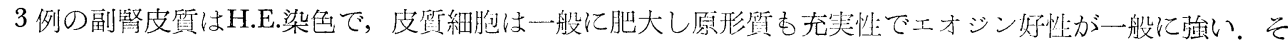
して特に束状層細胞索の排列は乱れ，同時に網状層或は束状層，殊に皮質内增の細胞に巣状にかなり強い変 性壊死像を認める。乙の壤死部の皮質細胞には核浱縮・原形質の空胞形成を認め，また一面に染色性の乏し い均等な凝固填死像のようにみられる部分屯認められて，特に 2 例においては皮質内首，殊に網状層細胞に

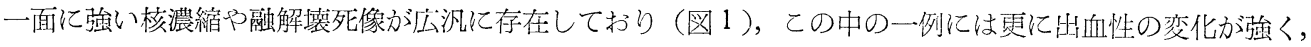
一側の副腎䯣質は殆んど血湖の状態をなしている(図 2 ).

組織化学的に屯皮啠細胞，特に束状層・網状厒に少られるSudan 顆粒は微細化し，減少または消失して おり(図 3)，Schiff 反応或はA-S反芯所見むSudan 染色の埸合以上に陽性顆粒の減少が強い。このような

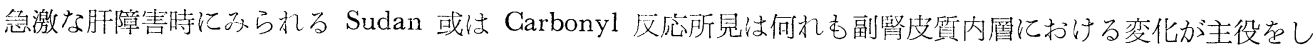
め，一般に糸球層の脂肪顆粒ては余り著变のないととか注目された。そしててのような変化は皮質の自御螢

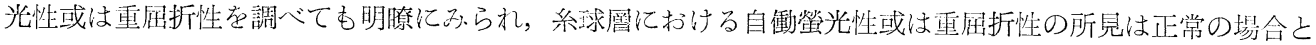
余り大差はない，ところが Schultz 氏反応を施して沗ると，副婜皮質における反応は全くみられず，皮質 内首部は勿論糸球畨における Cholesterin 顆粘も組織化学的には全く認められなかつた。一方S-D反応によ

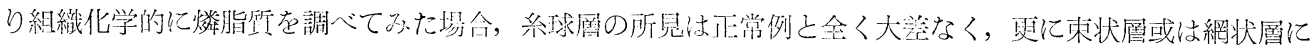

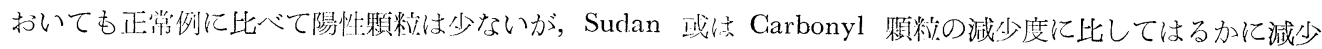
の程度は少い。

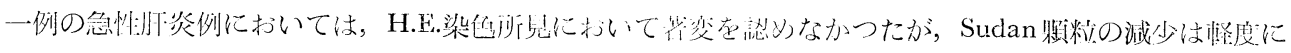
第36瓷 第 1 号 
みられ，また Schiff 反応・A-S反応むかなり減少していた。 こして Schultz 氏反応の陰性化か強くみられ， 急性肝疾患例の副腎度質飞おいては Schultz 氏反応陽性物質—Cholesterin の反応が最屯鋭敏之思われた。 これに反し S-D反応一一燐脂啠反応の減少が最むゆるく認められる点も興味深い.

\section{(2) 亜急性黄色肝菱縮症}

この場合は副腎皮質の所見は，上述の急性肝萎縮症の場合に比べ次第に回復した像がるられ，脂肪顆粒す 皮質の各所に不規則に現わ机始妇 4 )，次第に復元して肝硬变，特に続発性肝硬変時の所見に近ずいてき ている. 即ち発病後21日死亡例では，H.E.染色所見で副腎皮質は好エオジン性が強く細胞は一般に肥大性で あるが，皮質全域に亘つて余り退行性ないし壤死性の病変はみられなかつた。勿論出血性変化むみられず， 皮質細胞索の排列む一般に整然としている。本例を組織化学的にしらべた場合, 皮質細胞のSudan 陽性顆 糔は尚少くSchiff 反応・A-S反応む一般に非常に微弱であり，また Schultz 氏反応によるCholesterin も 少く，燐脂質反店む一般に微弱である。重屈折性・自働螢光性む副警皮質全域に亘つて殆んど認められず， このような所見は或は長期間持続している黄疽の影響によるものとも考觉られた。しかし乍ら巣状に図 4 亿 みられるようなSudan 陽性斑か限局性に特に束状㐿の外側部に散在してみられ，該部におけるSchiff 反 応・A-S反応子陽性である。同時に Schultz 氏反応・自働螢光性或は重屈折性も陽性にみられ，Schultz氏 反応むかなり強い陽性を示していた。 しかしS-D反応は正常時のそれに比しやや反応が弱い，そしててのよ うな部分の副擟皮質細胞は，H.E.染色によると原形質が非常に淡明であつた。

亜急性黄色肝萎縮症の他の 2 例は何れも更に経過が長く 1 ～～用間経過したものであるが，副腎皮質の 組織学的所見は前者の場合之は異なり, 副腎皮質特に束状首・網状層の脂肪量はかなり多くなつて来ている. 同時にA-S反応・Schiff 反応は強くみられ，Schultz 氏反応・自働螢光性・重屈折性或は燐脂質反応等もよ く認められた。 しかし糸球首にみら机た脂肪量は非常に少く, しかむ脂肪顆粒は著しく微細であることが注

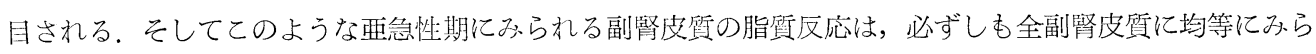
れるすのとは限らず，特に一例においては左右の副蹐によつて非常に趣きが異つていた，換言すると急性肝 炎から西急性ないし慢性に移行するにつれて，副腎皮質の脂肪量はかなり回復して後述の肝硬変にみられる 皮質所見に近ずくあのであるが，その回復速度は副㛑皮質の場所によりかなり異つているものというととが

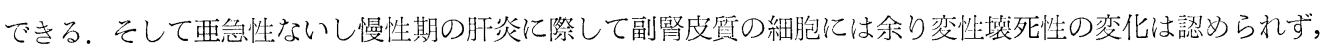
また一般に細胞には充実性の肥大像がみられることが特長のように思われた。

\section{(3) 肝硬変症}

肝硬変特に Laennec型萎縮性肝硬変症と考えられる症例で㽷中17-KS挑泜量が薯しく低い例においても， 皮質の形態学的変化は比較的少いことが注目される.

(i) Laennec 型萎縮性肝硬変症

私の経験した 21 例中 13 例においては，因眼的にもまた顕微鏡所見においてす特記すべき変化はみられなか つた，即ちH.E.染色では大部分の皮質束状層細胞の原形質は一般に広く，非常に淡明であり，核は比較的小 さくて浱縮型を呈し細胞の中央部に位㽞しており, 丁度泡沫細胞様の所見を呈するものから成立つている. これに反して，糸球首細胞は原形啠む椆密で好エオジン性が強い. 更に束状首の最内層吕ら網状層の細胞に かけてもこの傾向がみられるが，また同時に細胞は萎綰性を呈しているすのもみられ，間所結合織ないしは 毛細管内皮細胞の增生も著明である，こして網状層細胞にはかなり著明な褐色色素ないし消耗性色素の沈着

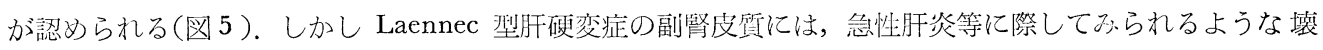
死像は全く无られず，また広沉な出血性の変化も認められなかつた。

組織化学的にしらべた場合，皮質にすら机る脂肪量にも著変はない。むしろ束状缯細胞特に上述の泡沫細 胞様に認められた部分にはS Sudan 染色に上り非常に多是の脂肪滴が認められ，その大きさも非常に粗大で 原形質を一面に充满している(図6).こしててのような部分には Schiff 反応・A-S 反応(図7)がすべて强陽

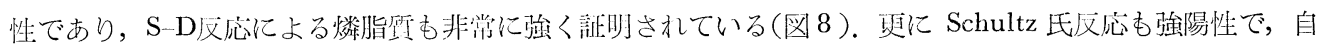

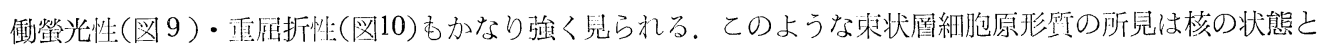


併せ考えた場合，明らかに眝藏型の脂肪所見を是しているものとみなされ，皮質細胞のホルモン産生は正常 であるにあ拘らず，比輘的分泌が低下した際の所見に一致するものということができる，そしててのような 所見は21例中13例に認めることができたので，かなり萎繀性肝硬変症に際して見られる副腎皮質の形態学的 所見の一特長と考えるととができる.

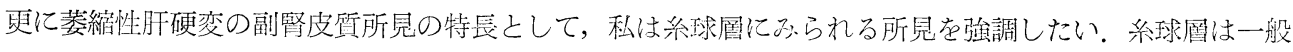
に幅がやや厚くなつており，H.E.染色によつてかなり原形啠の应土オジン性が強いのであるが，Sudan 染色 を施した場合非常にその脂肪量は少く(図 6 )，しかむ顆䊀を原形質に允満している東状首のそれ之は全くよ い対照を示して明膫に系球層の存在を見分けるととができる。Schiff 反応・A-S反応は著しく弱く(図 7), S-D燐脂質反応(図 8 )屯微細であるが，更に Schultz 氏反応・重屈折性(図10)或は自働螢光性(図 9 )屯全く

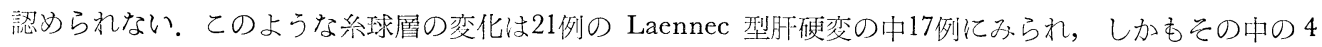

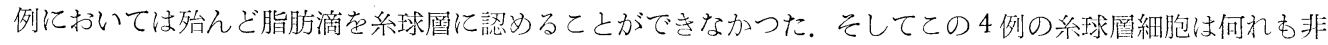
常に強い菱縮性の変化を示していた。

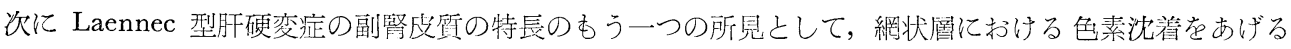
ことができる(図 5 )。本色素はやはり Sudan 可染性であり, S-D反応も強く認められ, Schiff 反応・A-S反

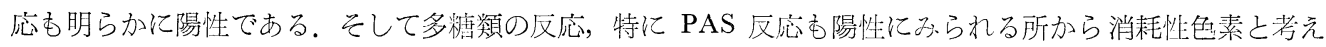
られ。また鉄反応は陰性である所から Haemosiderin とは全く別個のあのである.

しかし乍ら，21例の Laennec 型肝硬変の中で他の 8 例の副腎皮質所見においてほ，上述の上うな一定し

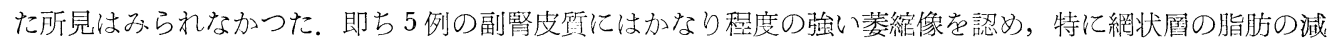

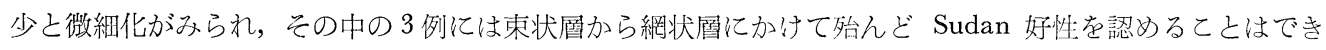

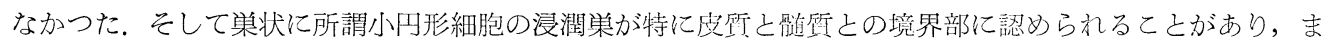
た非常にうつ血性あるいは出血性の強い所見むるられた。

3例の副腎皮質においては肉眼的にも顕微鏡的にも著变なく，特に Sudan 染色によりかなり多量の脂肪

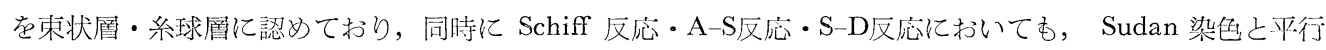
した所見を示していた，重屈折性・自働螢光性む正常副緊皮㙄之同じであり，何ら異常はぬられなかつた。

(ii) Hannot 型肥大性肝硬変症

尚私は一例のこの型の肝硬变と考えられる症例の副腎皮質を検索する機会をえたのであるが，その形態学 的所見は前記の Laennec 型肝硬変のそれ之全く同様の所見を示しており，何ら認めるべき差異はるられな

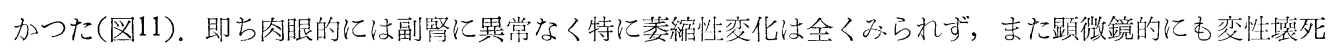
像はみられないが，Sudan 染色・Schiff およびA-S反応等を行つた場合，束状硎の脂肪はかなり粗大なむの

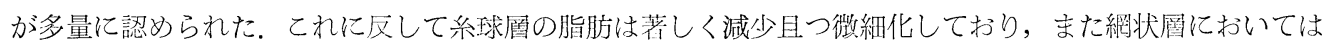

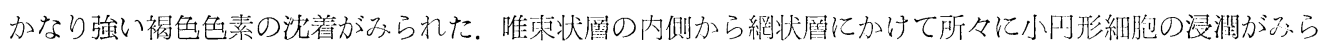
れたことがやや趣きの異つた所見といえる.

(iii) 胆汁うつ滞性肝硬変症

16例中11例に概ね共通した所見がえられた。即ち Laennec 型肝硬変の際と同じ因腿的には多各んど著変 がなく，萎縮を思わせるすのはみられない，こして因限的に皮颃の黄色調が著しく少くなつている点が特長 的であつた。

顕微鏡所見においても，H.E.染色で皮所細胞の原形所は一般に充実性で好エオジン性が溞いのが注目され

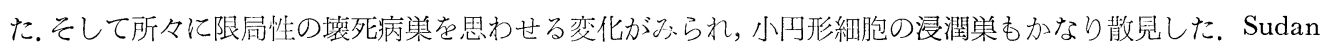

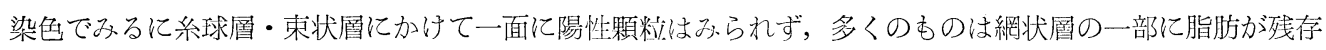
しているにすぎない(図12)，そして Carbonyl 反応むSudan 染色のそれと同じ所見を示し，Cholesterin 反応・重屈折性・自働營光性は㱠んど副婜皮質の全域に認められなかつた．S-D反応は残存している網状圆 の脂肪に強く認められ，乙の部分のSudan 陽性顆粒は非常に Acetone 難溶性を示していた。

他の 5 例の胆汁うつ滞性肝硬変例においては，一定の変化はすられない，即ち斑点状・限局性に所々の副 


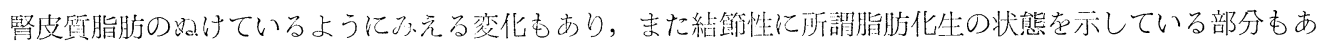

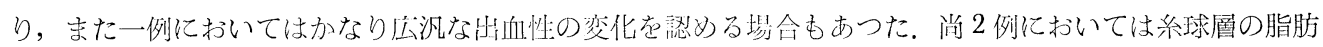
が著しく多いあのああり，また一例においては絿層の幅が著しく狄く萎䋉性のあのあみ.られた。

(iv) うつ血性肝硬変症

本症の 2 例においても，因眼的にも顕微鏡的にも著変はなく，Sudan 染色に上る所見にも余り異常を認め なかつた，束状首においては粗大な脂肪顆粒が多量飞認められ，特に Cholesterin 反応り重屈折性が強くる. られた。そこして注目すべき变化として，整度ではあるが系球層にみられる脂肪量はやや減少・微細化の傾问 にあり, また正常に比してやや糸球首は厚くなつているように認められた。

（v）笴生虫性肝硬変症

2 例の日本住血吸虫症の副腎を検索したが，肉腿的には著変がない，顕微鏡的には Laennec 型肝硬変時

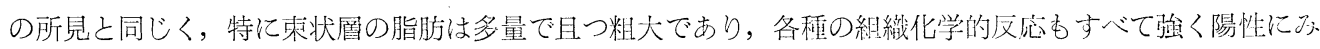
られた，糸球層の脂肪は正常よりやや減少し，顆䊀も一般にやや微細化している，一例の副腎皮啠の網状層 の部分には充血か強く，一部に出血性の変化がるられると共に，かなり強い皮質細胞の空胞変性ないし藵死

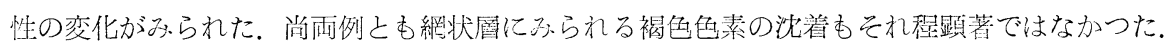

\section{(4) 肝臟癌}

(i) 原発性肝臟癌

37例中 35 例に肝硬変症の合併在热めている。气してての中の 21 例において大体上述の萎䌏性肝硬変症の場

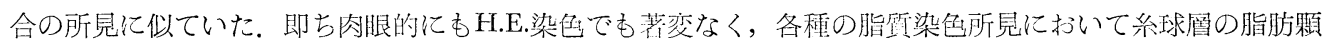
䊀の減少並びに微細化がみ、られ，束状屬の脂肪量は正常またはやや增加しており(図13)，著しく粗大な顆粒 が皮質細胞の原形質にかなりるられた。

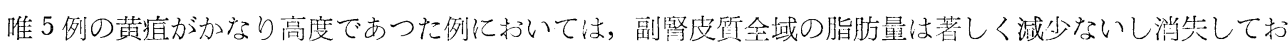

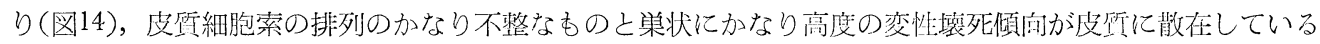

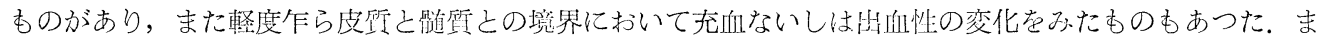

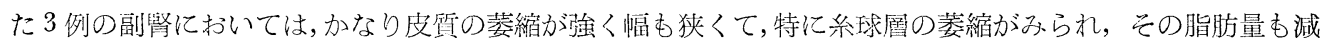
少・微細化しているあのがあり，また糸球層における脂肪量が割合に維持されているものああつた。 ての症

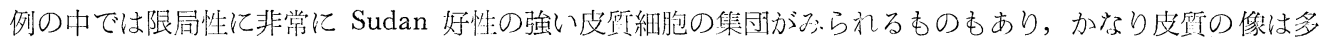

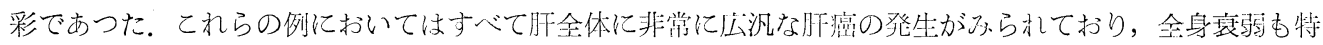
に著しいと考えられたあのである。

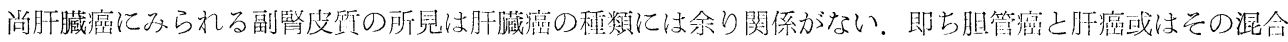

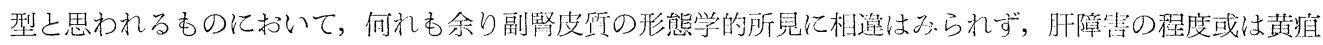
の強さがての副腎皮質の所見に対して最も大きく影響しているように考觉られた。

(ii) 転移性肝蔵癌

胃癌・直腸癌・肺癌等のかなり強い肝転移の3:られた症例29例について副緊皮岓の検查を在行つたが，特記 すべき一定の所見をみるととは出来なかつた。唯非常に肝への転移が広沉であつた 9 例のうち 5 例に，副緊

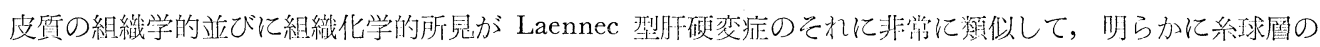

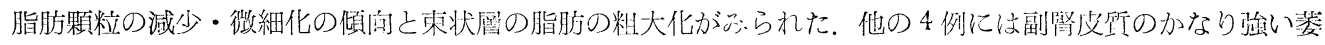
縮と脂肪の減少・消失を認めた。

他の肝臟への転移癌の 20 例においては非常に变化が多彩で，H.E.染色標本において全く変化をみ、ない屯の

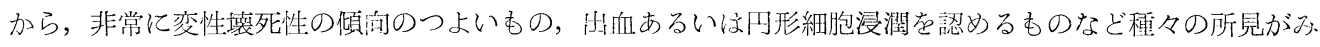
られ，また脂肪染色所見に㭁ても，全く正常之考光られる所見を示しているすのから非常に脂肪の分布の 不規則なむのや或は著しく脂肺の娍少している例もるられ，一定した結諭をうるととはできなかつた。

\section{II. 性 腺}

\section{(1) 卵 巣}




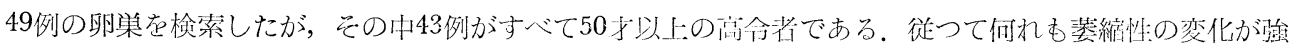
く認められているが，乙れはむしろ生理的な加命睍鼠と考える心゙きものであらう。

50才以下の症例の卵宩を子ても慢性肝疾患に際しては，著变のない場合が多い．即ち組織学的には勿論変 性性变化は少く，唯 2 例の卵巣においてかなり卵胞形成減退の像がュ.られ，卵胞の顆粒膜細胞並びに内莢膜 細胞にやや萎縮を思わせる恋化を認めている。

脂肪染色では著明な变化はる.られないが，内苂膜細胞の脂肪顆䊀がやや粗大にる、られ(図15)，また黄体細 胞の脂肪がかなり粗大化している場合が認められた。そして閒斦がやや增生し浮腫状にるられる場合むあつ た.

\section{(2) 睪 丸}

85例の䅅丸を㭘索したが，その中の61例は45才以上の高令者であつた．從つてかなり年令による考虑を払 つて睪丸の組織像を解析しなければならないので, 特に45才から55才までの37例の等丸について詳細に検索 を行つた。

慢性肝疾患殊に肝硬変症の際の罣丸に於ては，肉眼的にも顕微鏡的にも一般に菱縮を強く認める。即ち一 般に精細管の大きさが減少し，基底膜が非常に肥厚している場合が多い。精細管内の精子形成は著しく減退 しており(図16), 精子細胞を中心とする精細胞にはかなり䖽度の強い变性ないし酒死所見がよく見られる。 勿諭, 精母細胞の萎縮ないし退行性变性像がみられ, Sertoli 細胞がかなり明瞭に認められる場合が多かつ た. 问精母細胞の変性型と考えられる水腫性肥大を示している巨大精母細胞の出現すみられることがあり, また中には非常に精細管の変性萎絈が強くて始んど基底膜のみ沈なつているものあみられた。

間質においても一般に結合織の増生がみられるが，Leydig 細胞は正常か或はむしろやや増生肥大の傾问 のみられる場合が多かつた（図16)，そして所によつてはかなり集団を形成しており，中に含まれる Sudan 顆粒はかなり粗大傾向がみられた。 勿論 Leydig 細胞の原形啠にもA-S反応・Schiff 反応がるられ, Schultz

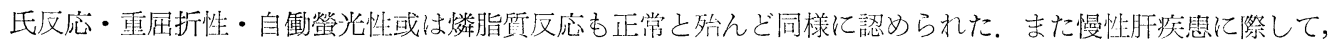
この Leydig 細胞の原形質においてもかなり褐色色素を多量に沈着している場合が多く，てのものは脂肪反 応が陽性で PAS 反応等の多糖類反応屯陽性であり，鉄反応は陰性である所から副腎皮所網状層にるられる あのと同じく消耗性色素の一種と考えられた.

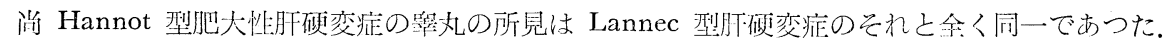

\section{総括並びに考按}

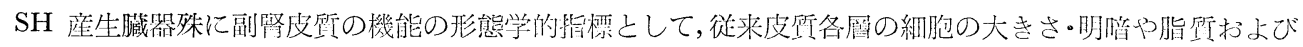
KS の量・顆粒の大きさ・粗密等があげられている ${ }^{11,12,26,30,31,39,34)}$. しかし特に人体の副腎皮欣は局所によ つてかなり形態学的所見に相違がみられ，その像が極めて多彩であるき5゙. また剖検材粈による SH 産生藏 器の形態学的変化は直接死因・合併症・年令・性・栄養状態等の種々な因子の影響をうけて，その所見の解

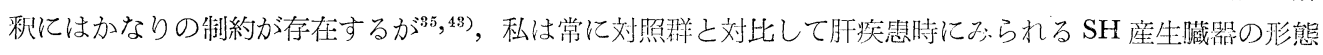
学的所見の特長を把握するように努力した.

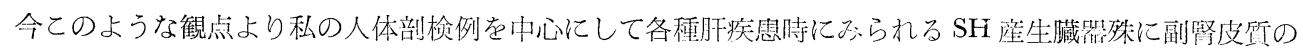
形態学的所見を総括し, 且つその際の機能検査成績とも対比して, 朋疾思におけるSH 代謝の異常が主とし て産生相と代謝相との何れの障慧に由来するかについていささか考察を加えてみた.

副腎皮質にみ.られる出血性変化抢よび空胞形成は，急性感染症等によくる.られる変化であるが35)，私の急 性肝萎縮症例においても同様の所見が認められた。 そして前述のような皮啠所見は，その病原であるウイル スが肝を侵すと共に副腎を直接傷㫪するために強い退行性変化を来たすすのとも考えられるが，むしろ Albrich $^{1)}$ 等も指摘しているように下垂体副腎皮所系の機能立進時の所見と解勫される. 即ち流行性朋炎の急 性期ないし劇症肝炎——急性黄色肝萎縮に拀いては一般急性感染症 ${ }^{17)}$ と同怺に激しいストレスに曝されるた

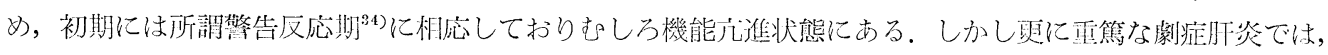




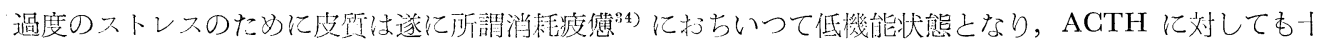

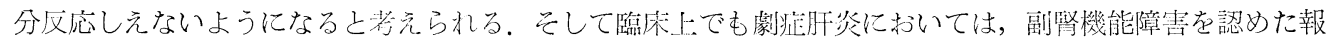

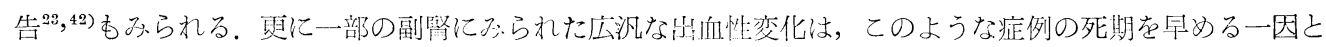
あなつているもの之考觉られた。

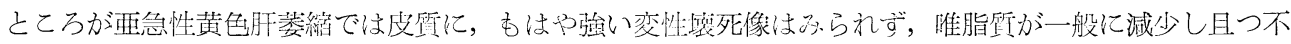
規則な排列を示す程度であつた。それ故肝炎が急性期を経て西急性または慢性の経過资とつた場合には，皮

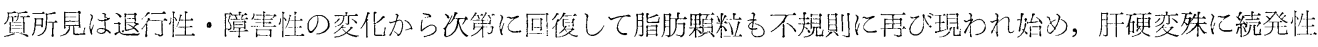
肝硬変時の所見住変つて行く.

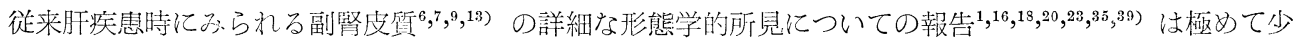
く，急性肝突患殊に肝炎についての報告は特に少い。唯 Albrich ${ }^{1)}$ は私のえた所見とほば同様の結果をえ，て の他に糸球層の菱縮を特に指绱しているが，私の検索例ではこのような糸球尿の所見は急性例ではる゙られな

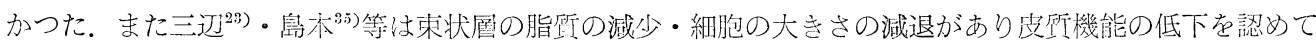
いるが，その他の報告では急性と慢性と等全く同栐に取扱つて去り，特に急性肝疾畺に特有な所見を明らか そしたあのは少ない1).

私のえた成績によると，同じ肝炎であつてもその重篤度・経過ないし病期によつて副腎皮所の所見はかな り暴つているが，従来の文献ではこの点について十分な考虑が払われていないために，一定した所見をうる

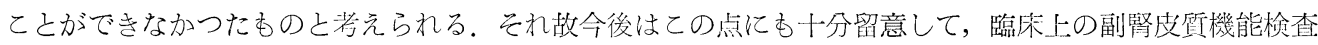
成績を評俩せねね゙ならない。またての事柄は劇症肝炎——急性ないし亜急性黄色肝萎縮の治療に際して，

ACTH 或は CS が有效であるという臨床上の経験的事実と併せ考えると甚げ眮味深く思われる。そして私

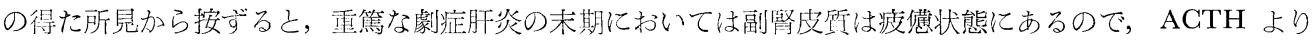
あむしろ CS 製剤投与の片がより適当と思われる。

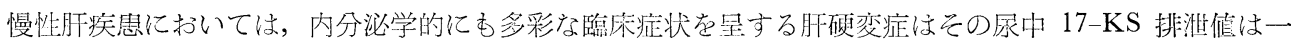

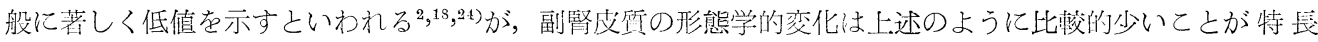

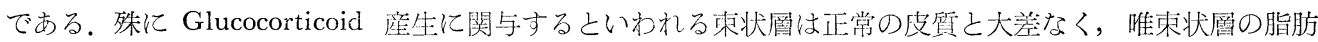
顆粒は粗大で量む多く所謂损荗型の脂肪所見に一致して，皮質のホルモン産生が分泌よりあ多いことを示す あののようである。そしてこの事実は肝硬变症においては尿中および血中 CS 量は涜奖正常域にあり，

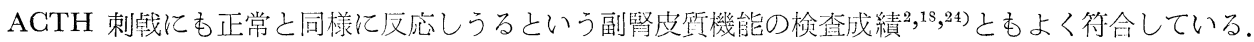

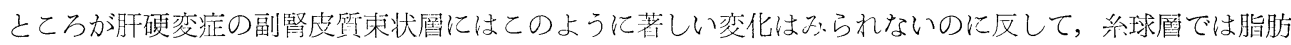

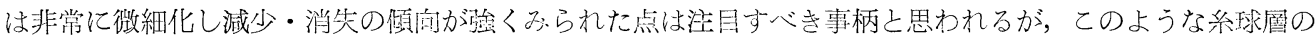
变化は僅かに Albrich ${ }^{1}$ によ指摘されているのみである。そして糸球層からは Mineralocorticoid 殊に Aldosterone が産生されるといわれ，且つ肝硬変症の尿中 Aldosterone は一般に增加して所謂 Secondary

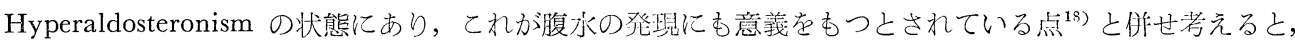
上述のような糸球層の所見は興味あるものがある。即ち肝硬变症の副婜皮啠糸球磨の大部分のものには脂肪

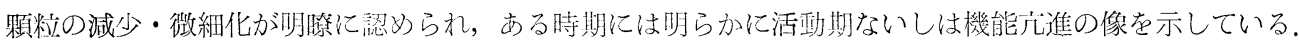

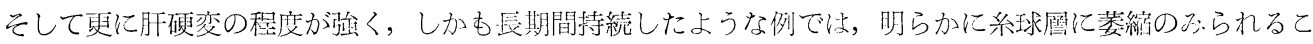
とが注目された。

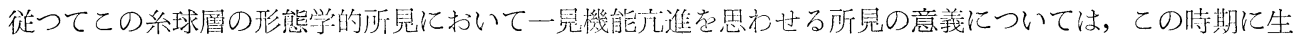
体内の $\mathrm{SH}$ ，殊に Aldosterone または水分・塩類代謝の巽常が起つて，糸球尿の需要が艺まつて来たため

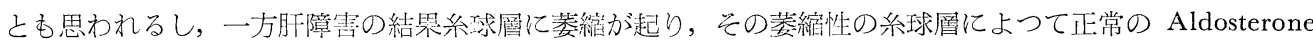
産生或は水分・塩類代謝在代償している結果，一見機能が兄進しているように見えるのか断定は難しい. 從 つてての糸球層の変化の意義については，Aldosterone 代謝の栄明と共に，腹水を来たす他種の疾患との対 比や肝硬变のうちの腹水の有涠による相違点等について尚榆討存要する点が多く，今後の解明が望まれる.

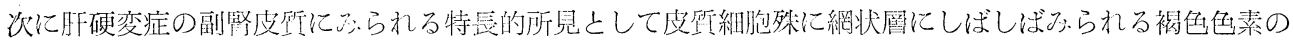


沈着をあげうる。乙の色素は前述のように Haemosiderin とは異なり Lpiofuscin と考觉られ，通常年令

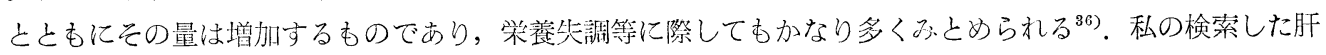

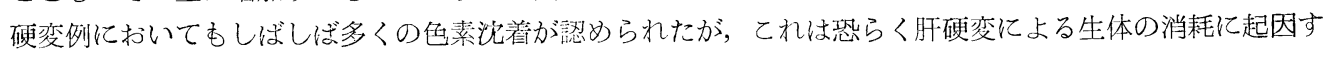
るもの上考えられ，対照とした他の肝以外の腫㛫或は消耗性疾畫にも僌度乍らみられた。

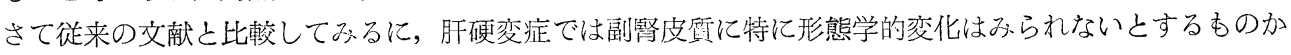
$ら^{7,13)}$ ，非常に重篤な所見がみられるとするすのまで,139，種々な報告がなされているが，一般には肉眼的に やや小さく $6,16,20)$ 殊に皮質はかなり高度に萎縮して溥くなり ${ }^{6,20)}$, その脂質の減少が著明であるとする報告が 多い1,16,20,39). そしててのような变化は束状層に著しく，局所的な脂質の減少や結節化屯認められ，また皮

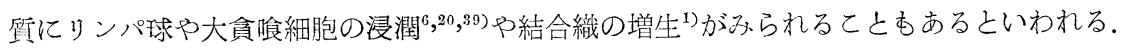

私の検索した症例の中その一部（５例)においては，皮質にかなりの萎縮を認め，特に束状首の脂質の減少 微細化がみられたが，乙れらは何れあ甚でしい全身衰弱または黄疽を伴つているあのであつた。そしてその 他の大部分にわいては前述のような萎縮は余り認められず，糸球層の脂質は微細化し減少・消失していたが， 束状層においては脂肪顆粒は粗大で量も多く, 從来の報告之はかなり異なつている. としててのような相違 は従来の報告では皮質各層における機能の局在性関する知見が当時は十分に知られておらず，且つ全身状 態や黄瘨の有無についての分析が足らなかつたためと考えられる.

腫煬性疾患による副腎皮質の形態学的変化については，Landau (1915)・Dietsch-Siegmaud (1926)・西野入 (1934) 等の記載があるがその所見は種々であり，脂犋についてあ娍少する場合や逆に增加する場合すみら れて，必ずしも一定していない咅．私の例においてすしばしば肝硬変を伴う肝癌では上述のようにほぼ肝硬 変の際の副㹂所見と同一の所見をえたのに反し，転移が余り広汎でなく肝障害も余り強いとは考えられない

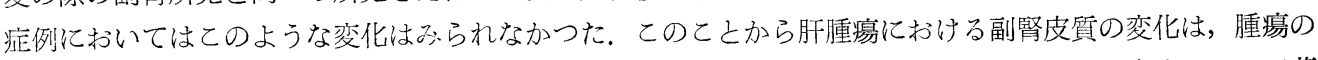
種類よりあむしろ肝障害の程度に深い関連があるものと考えられる。またての事実は，肝硬変症において萎 繀性・肥大性・続発性・寄生虫性・うつ血性等その原因には著しい差異がみられるにも拘らず，皮質所見は 末斦的にはほはば同一の様相を示した事実ともよく符合し，副腎皮質の形態学的所見は肝障害をひきおてす原 因には余り関係なく，むしろ肝障害の程度ないしはとの持続期間と深い関連があるととを示している。

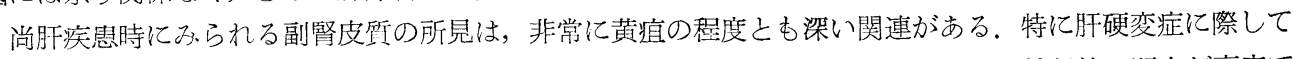
肝不全の程度が重篤になり強い黄疽か現われたような場合や，Vater 氏乳頭癌等の総輸胆管の閉塞が高度で あり強い閉塞性黄瘨の現われたような際には，例外なく皮質束状層の脂肪顆粒は減少消失し，もともと肝障

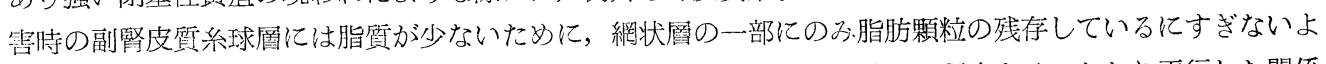
うな場合にしばしば遭遇する。こしてての黄㥀の程度と皮踶の脂啠の減少の程度とは，かなり平行した関係 にあるととは興味深い，荒不”豆黄疸時の副腎皮質には一般に萎縮が強く脂質の減少が著しいと述べ，また 閉塞性黄瘨にわいては尿中 17-OHCS 排泄佔は比較的低值を示し, 且つ ACTH 刺㦸および外科的侵襲に対 してそれに対応する尿中 17-OHCS の增加は正常に比してかなり低いことが知られているが ${ }^{14)}$ ，てのような 形態学的所見之併せ考光た場合, 高度の黄疽の際には副䜿皮所細胞の機能はかなり荒廃を来たしているすの と推測される。

また肝腫癔に際して消耗の积度が強く全身の琶液所の甚だしい埸合にも, 束状層の脂肪顆粘の減少・微細 化の傾向がみられる。

從つて副腎皮斦の形態学的所見を観察する際には，常に肝機能障害・黄疽並びに全身衰弱の程度を十分考

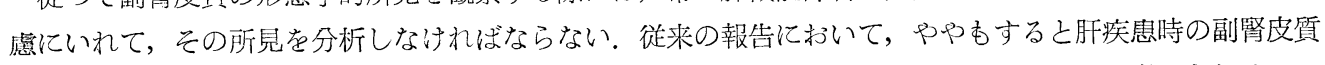
所見に必ずしも一定の所見菓得られなかつた理由は，てのような分析が足らなかつたためと考えられる。

最後に肝疾㭧に際してみ:られる性腺の形態学的所見について一言する.

慢性肝疾恵殊に肝硬変症に際して，睪丸に肉眼的に菱縮が認められるととは古くより注目され，Kyrle (1902) Weichselbaum(1910) が初妙て記載し，その後Corda(1925) Silverstrini (1926) がこれを内分泌失調に

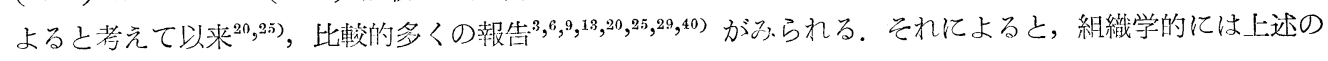




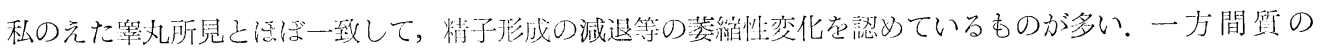

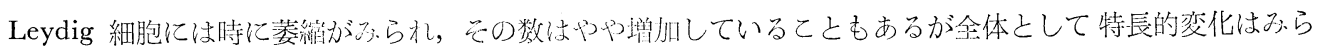

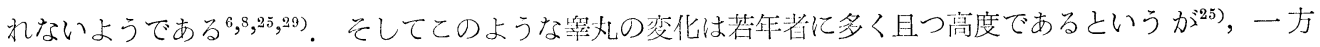

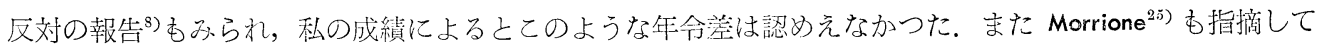

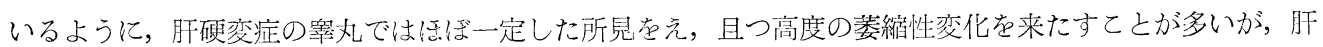
硬変以外の肝癌・閉塞性黄瘨等に伴う肝不全例ではその結果は種々で一定していなかつた。

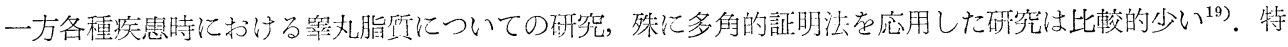

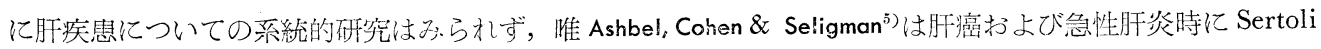

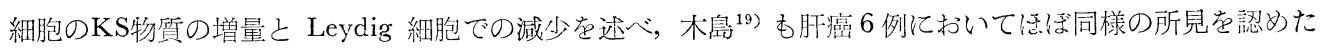

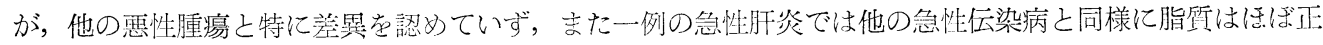
常であつたと述へている。悡のえた所晃においても，Leydig 細胞にはSudan 染色・A-S 反応等において 顆䊉がやや粗大となつている他，特記す心゙き变化な見出しえなかつた。

このような睪丸の変化は，堽篤目つ広沉な肝障害が長期に亘り存在した埸合 ${ }^{25)}$ ，まずSH殊に Androgen・ Estrogen の代謝に異常が起り二次的に発現したすの之考光られる。しかし精子形成の障害のみは急性肝炎

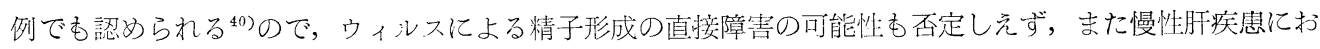
ける精子形成の障害はやはりそつ一部は全身衰弱或は栄養障害に起因するものと考えられる。

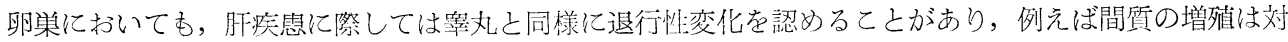

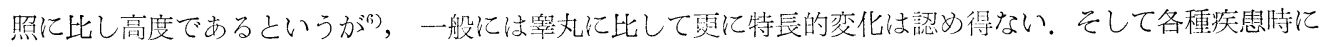
みられる卵巣の組織化学的所見についての報告は極めて少く，且つその特長的所見は尚明らかにされていな いようである ${ }^{15,211}$.

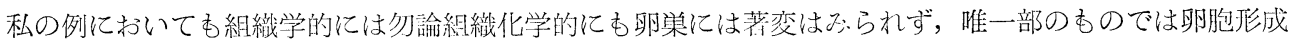
減退の像がみられれ。こして特にSH産生にあづかるといわれる内荻膜細胞或は黄体細胞内初にみられる脂

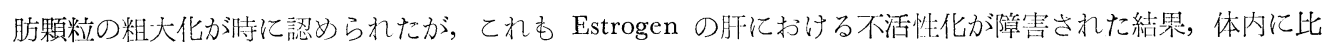
輍的過エストロゲン症を来たし，てれらの細胞からの Estrogen の分泌が抑制された所見とるなすととがで きる。

\section{結 論}

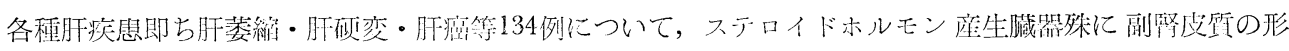
態学的研究を行つた。

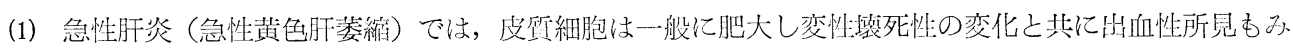
られ，また脂肪の微細化・減少消失の傾问を認める。

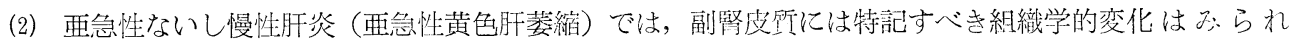
ず，唯束状圓の脂肪の減少と分布の不整が認められる。

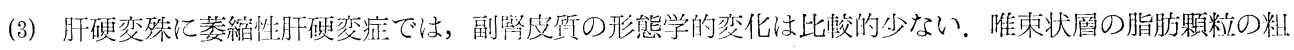

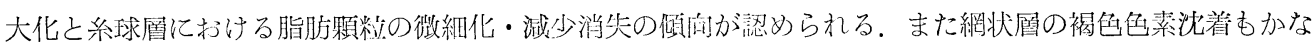
り明瞭である.

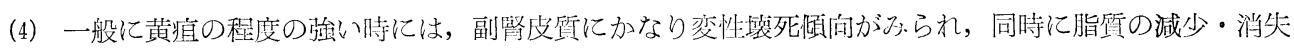

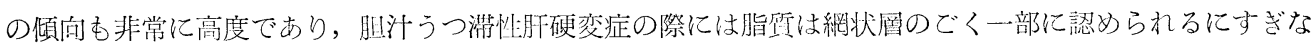
い.

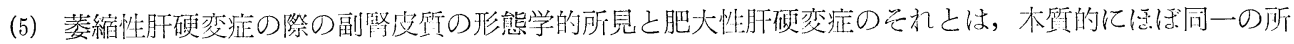
見を示している.

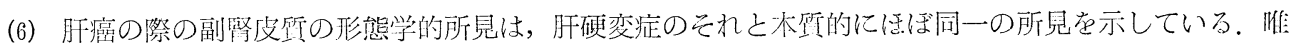
癌性変化か広汎で黄瘨が強く全身夌弱の高度な例では, 皮㙄の脂领は著しく減少・消失している。 


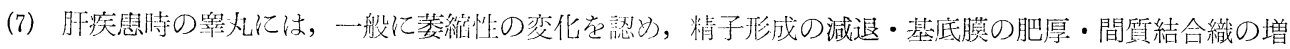

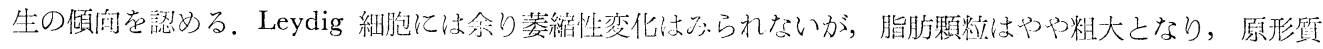
内にかなり多量の褐色色素の炏看を在る㘿合が多い.

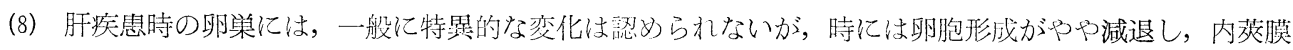
細胞および黄体細胞の脂肪顆粒の粗大化を認放。

(9) 以上の所見より，慢性肝疾舁殊に肝硬変症に品られるステロイドホルモンの代謝異常は，ステロイド

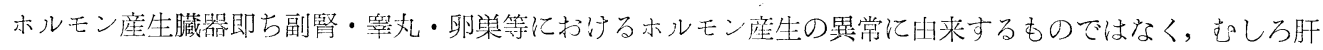
におけるステロイドホルモン中間代謝過程の異常に起因守るものとみなされる。そしてとのステロイドホル モン代謝の買常が続くことにより, 二次的にステロイドホルモン産生藏器の形態学的变化が为られるように なるものと考えられる。

本論文の要旨は日本内分流学会筙 6 回西日本地方会に打いて発表した.

擱筆するに臨み, 終始御懇篤な卸指導と御校閲を睗つた恩師二宅教授並びに種々御教示戴いた病理学教室 響川助教授に深謝いたしまず.

尚本研究は文部省科学研究費に負う所大であり, 記して謝意を表する。

\section{文献}

1) Albrich, E. u. Spies-Bertschlinger, A. : Acta Hepatol. 5, 117, 1957.

2）荒木嘉隆他：医学のあゆ

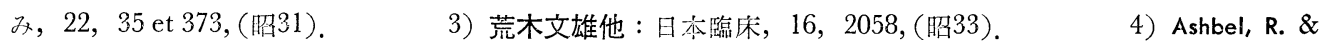
Seligman, A.M. : Endocrinol., 44, 569, (1949). $\quad$ 5) Ashbel, R., Cohen, R.B. \& Seligman, A.M. : Ibid, 49, 265, (1951).

6) Barr, R.W. \& Sommers, S.C. : J. Clin. Endocrinol., 17, 1017, (1957).

Barrelet, J. : Ann. d' Anat. Path., 9, 385, (1932). Cited from Lloyd. $\quad$ 8) Bennet, H.S. et al. : Am. J. Glin. Path., 20, 814, (1950). $\quad$ 9) Boccia, D. : Rev. Sui-amide endocrinol., 17, 416, (1934) Cited from Lloyd. 10) Capriglione, L. et al. : Presse méd., 42, 1419, (1934). Gited from Lloyd. 11) Deane, H.W. \& Seligman, A.M. : Vitamine and Hormones, Academic Press New York, 11, 173, (1953). 12) Dempsy, E.W. : Recent Progress in Hormone Research, Academic Press, New York, 3, 127, (1948). 13) Fittipaldi, C. : Pathologica, 25, 248, (1933). Cited from Lloyd. 14) Fuller, J.B. \& Schnewind, J.H. : Arch. Surg., 75, 462, (1957).

15) 布施正 : 東北医学雑誌, 18,62 , (昭10).

16) Givseffig, J. et al. : New England J. Med., 257, 796, (1957). 17) 長谷川弥人：日本臨床，14，23， (昭31). 18) 平山千圼：綜合鄵床，6，118，(昭32）；最新医学，13，198，(炤33). 19) 木 島一英：日内汹会誌，30，665，(昭30)。 20) Lloyd，C.W. \& Williams， R.H.：Am. J. Med. 4,315， (1948). 21）前田隆英：神戸医科大学紀要，3，59，(昭27)。 22) McManus， J.F.A.: Stain

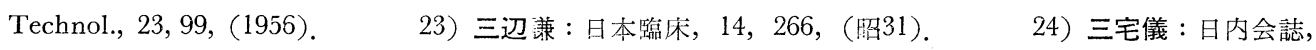
45，66，(昭32）；日本臨床，15，66，(昭32）。 25）Morrione， T.G.: Arch. Path., 37, 39，(1944). 26) 中尾健 : 副婜皮質ホルモン, 医学書院, 東京 (昭25). 27 ) 中山徹也他 : 内分泌之代謝, I, 60 et 95, (昭34). 28) Peris, M. : Virchows Arch. 39, 42, (1867). 29) Rather, L.J. : Arch. Int. Med., 80, 397, (1947). 30) Rogers, W.F. \& Williams, R.H. : Arch. Path. 44, 126, (1947) ; 46, 451, (1948). 31) Sagers, G. : Physiol. Rev., 20, 241, (1950). $\quad 32$ ) Schultz, A. : Zbl. Path., 35, 314, (1924). 33) Selye, H. \& Sione, H. : On the Experimental Morphology of the Adrenal Cortex, Charles C.Thomas, (1950). $\quad 34$ ) Selye, H.: Stress (The physiology and pathology of exposure to systemic stress), Montreal, Canada, (1950). $\quad 35)$ Shimamoto, H. : Acta Med. Univ. Kioto, 33, 1, (1955). 36) Smith, J.L. \& Mair, W. : J. Path. Bact., 13, 14, (1909) ; Dietrich, A. : Zbl. Path., 21, 465, (1910). 37) Stieda, H. : Zbl. Path., 4, 321, (1893). 38) Stumpf, H.H. \& Wilens, S.L.: Arch. Int. Med., 91, 304, (1953). 39) 高橋忠雄：日内会誌，42，633，(炤29). 40) Wood， 
D.A. : Arch. Path., 41, 345, (1946). 最新医学, 10, 1065, (畹31).
41) Wu, S.D. : Ibid. 34, 735, (1942).

43) 产村不二夫：日本䧊床，14，163，(䧂31）。
42) 山口与市他:

44) Leading

Articles : Brit. Med. J., 5056, 270, (1958).

\section{附図説明}

図 1 急性黄色肝箖縮の副腎皮質 (H.E.梁色)

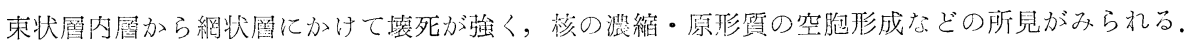

図 2 急性黄色肝萎縮の副腎皮質 (H.E.染色)

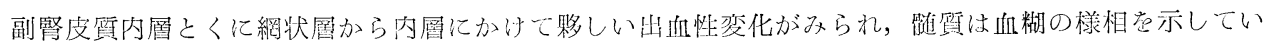

る.

図 3 急性黄色肝萎縮の副䝳皮質（Sudan 染色）

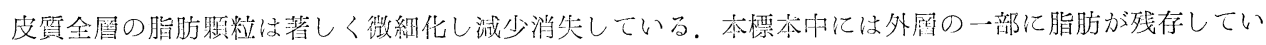

るにずぎない.

図 4 重急些朋萎縮の副㛑皮質 (Sudan 染色)

急些期に比して脂肪顆粒の量は回復しているが，その分布は甚だ不規則である。

図 5 萎縮性肝硬変の副腎皮質 (H.E.染色)

原形質が透明で大きな細胞とエオジンに比較的よく旅染ずる細胞群とが入り乱れ，所謂 zik-zak 苍形 成している。

図 6 菱縮烧肝硬变の副珡皮犋 (Sudan 染色)

Sudan 顆粒は束状層よ可網状層にかけて多く存在し，糸球層には余可垫められない。束状周の脂肪量は

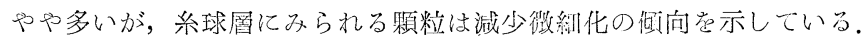

図 7 萎縮性肝硬変の副简皮犋 (Ashbel-Seligman 反応)

所謂 Ketosteroid 顆粒は束状層に最も多く正常時よりその量も多い.

図 8 萎縮性肝硬変の副腎皮質 (Smith-Dietrich 囚応)

燐脂質反応は主として束状層にみられるが，その量は正常のそれに比し余可差買は認められない。

図 9 萎縮性肝硬変の副腎皮質（自働螢光览）

自働螢光性は束状層から網状層にかけてみられ，その強さは正常時と余可相違はない.

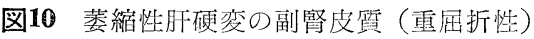

重屈折性は主に束状層に強いが，その強度は正嘗時と余句相違はない。

図11 肥大性肝硬変の副筒皮質 (Sudan 染色)

所見は萎縮性肝硬変のそれと全く同様であり，皮質内居部の脂肪顆粒が多い，

図12 胆汁うつ滞性肝硬変 (Vater 氏乳頭瘦) の副粲皮質（Sudan 染色）

皮質全啳の脂質は著しく減少しているが，網状層のみに脂肪は残つている。

図13 肝癌の副腎皮質 (Sudan 染色)

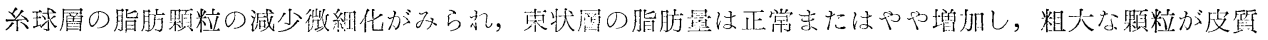

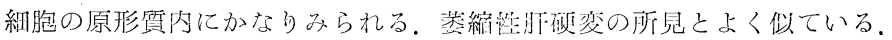

図14 肝癌（黄㾝高度）の副腎皮質（Sudan 染色）

副腎皮質の脂肪量は全体として減少し微細化しているが，内濖には Sudan 顆粒が残存している.

図15 菱縮性肝硬変の畉栄 (Sudan 染色)

特記すべき変化はみられないが，内萊膜細胞にみられるSudan 顆粒はやや粗大である。

図16 萎縮性肝硬恋の啐丸（H.E.染色）

精細管の菱縮が著明で，精子形成も娍迈している。間質細胞はやや增生し，裨色々素の沈着が多い。 


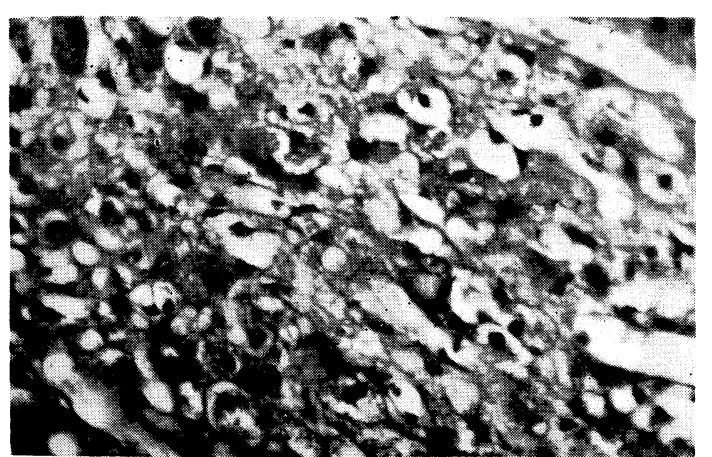

図 1

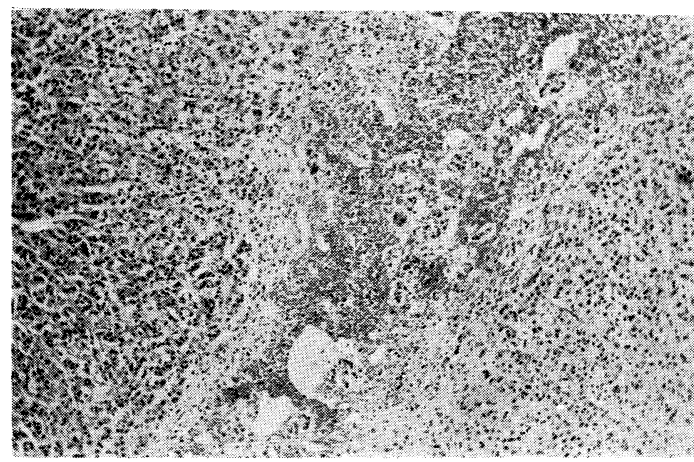

図 2

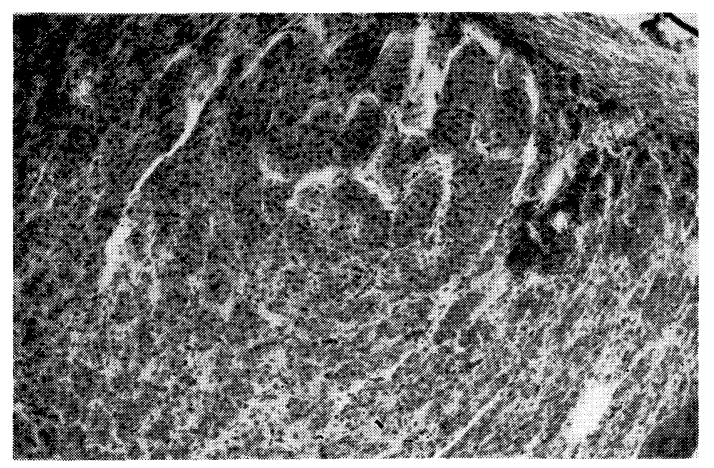

図3

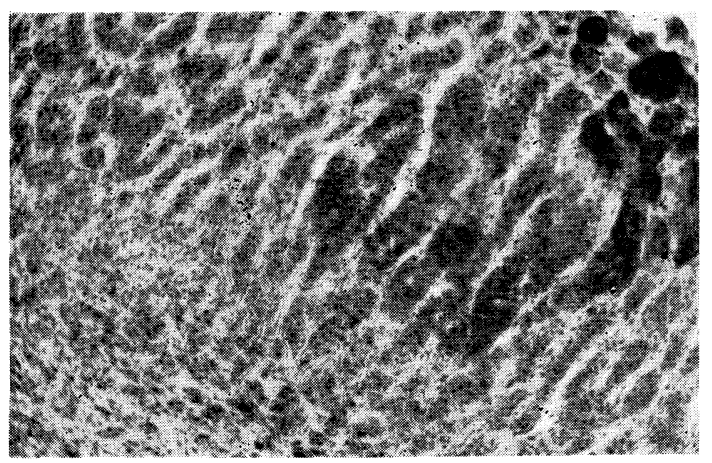

図 4

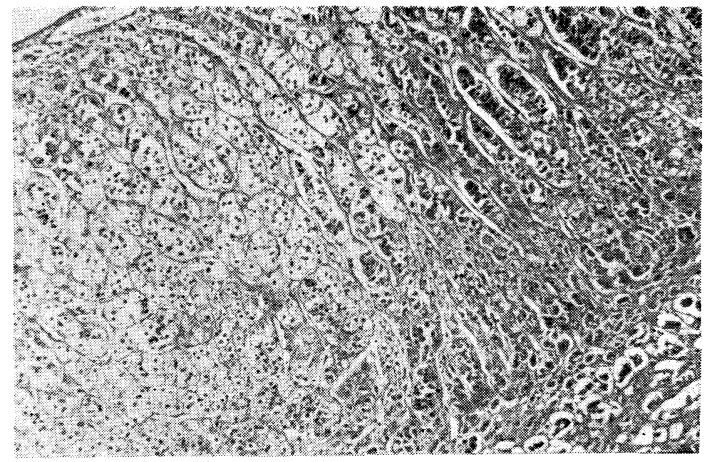

図 5

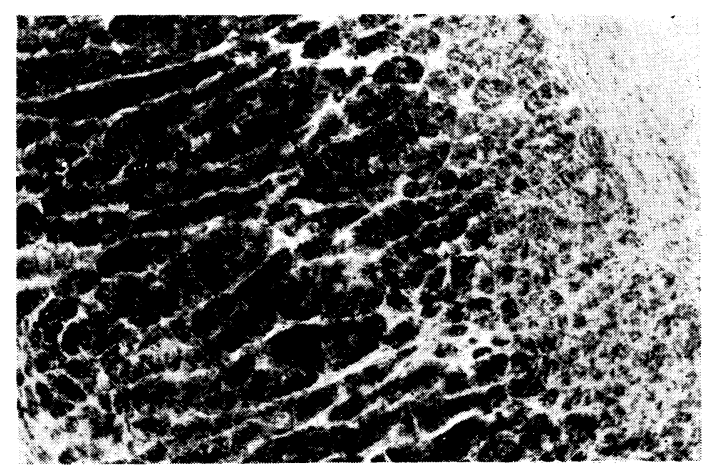

図 6

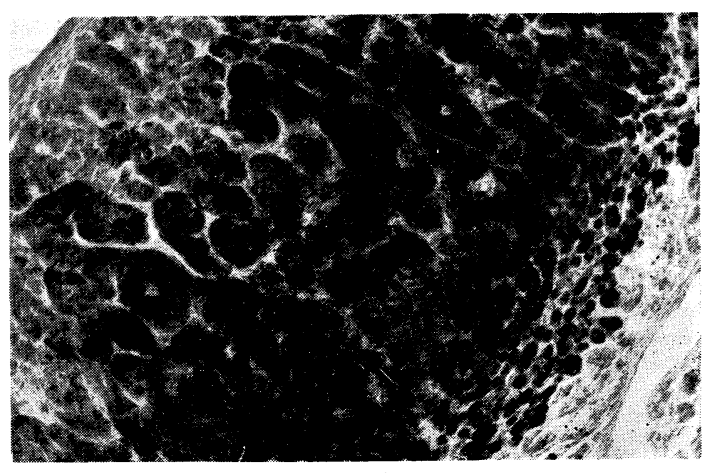

図 7

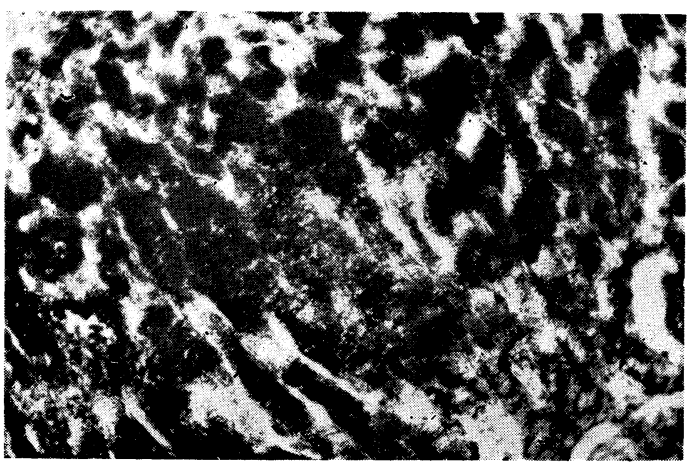

図 8 
村上論文附図（その2)

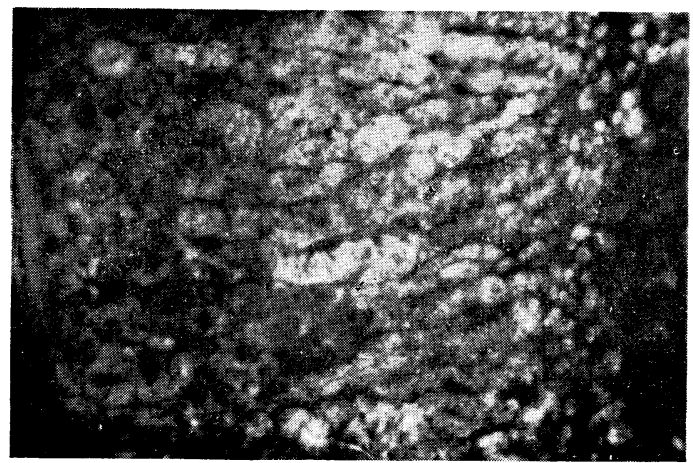

図 9

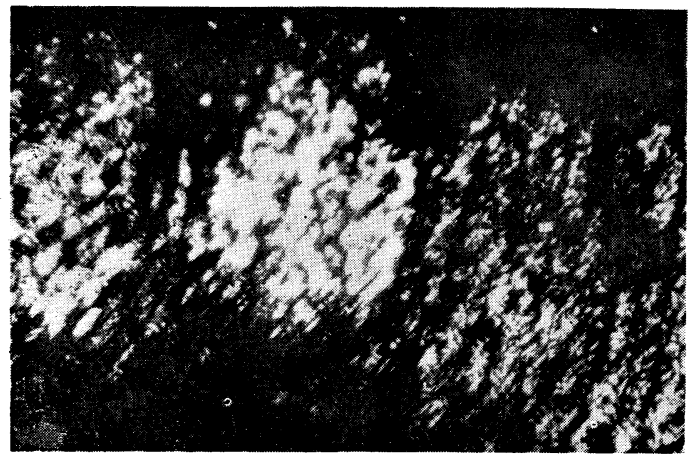

目 10

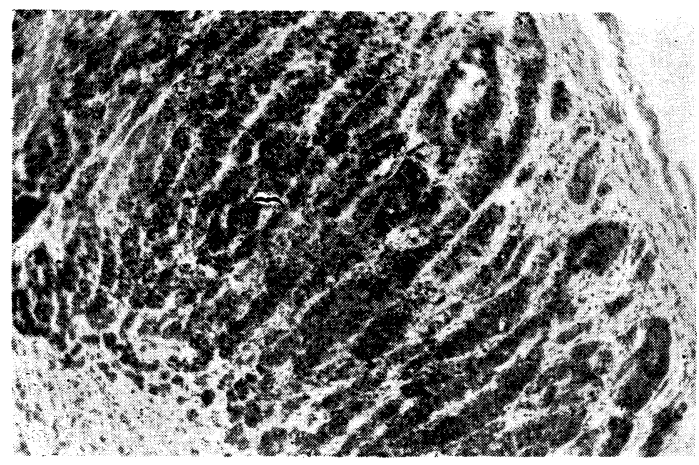

図 11

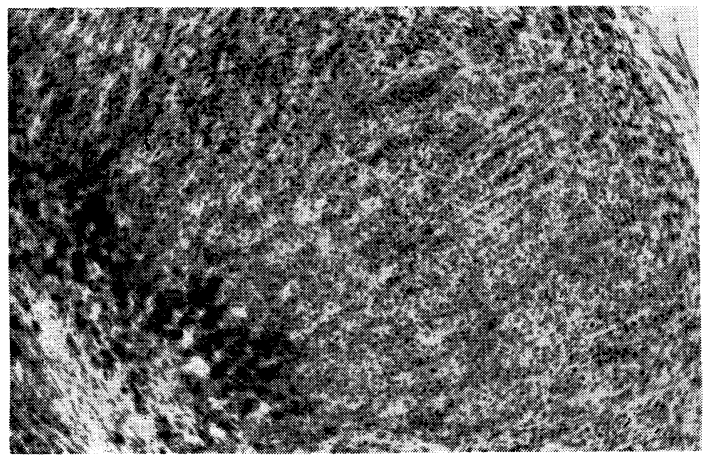

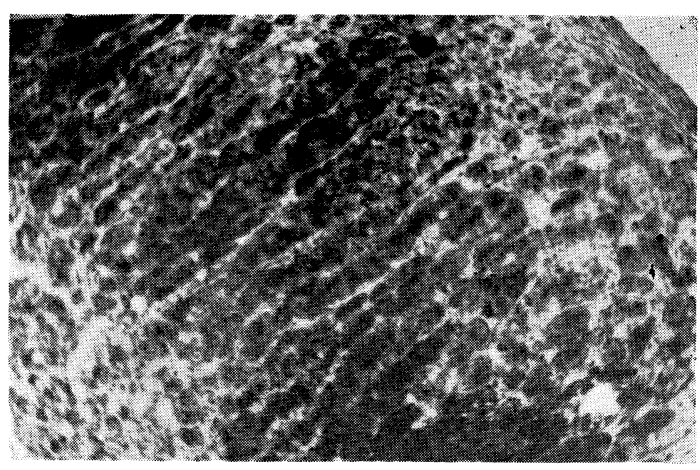

图 13

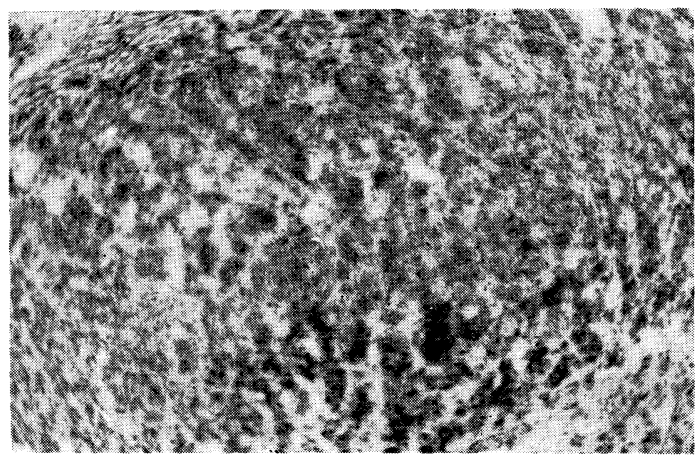

図 14

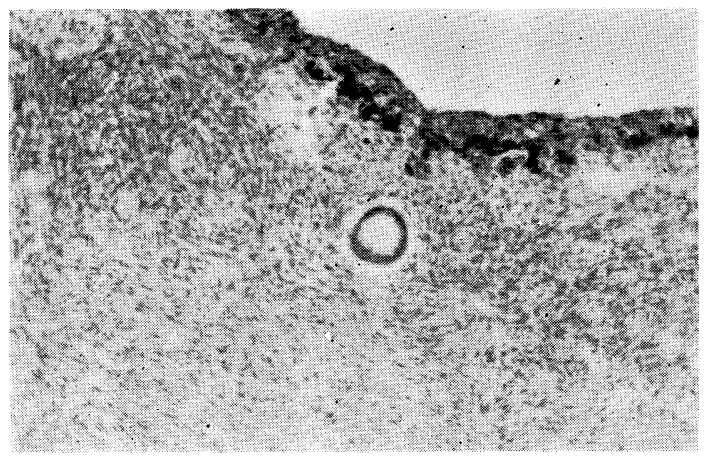

図 15

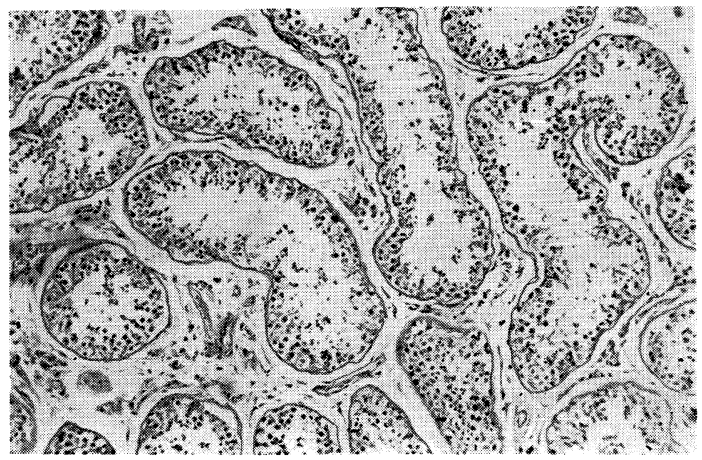

図 16 